\title{
GEOSHAPE DIGITAL: MEDIA PEMBELAJARAN DALAM MENINGKATKAN PEMAHAMAN KONSEP MATEMATIKA SD
}

\author{
${ }^{1}$ Mohamad Hariyono, ${ }^{2}$ Ernayanti Nur Widhi \\ ${ }^{1}$ mohamad.hariyono@ecampus.ut.ac.id, ${ }^{2}$ ernayanti.widhi@ecampus.ut.ac.id \\ 1,2Universitas Terbuka
}

\begin{abstract}
ABSTRAK
Pada mata kuliah Pendidikan Matematika II di Prodi PGSD dibutuhkan media pembelajaran sebagai motivasi yang dapat meningkatkan minat dan pemahaman mahasiswa. Dibutuhkan media pembelajaran yang inovatif, interaktif, dan mengikuti perkembangan teknologi informasi. Media pembelajaran Geoshapes Digital sebagai alternatif media dalam menunjang materi geometri materi Keliling dan luas mata kuliah Pendidikan Matematika II. Tujuan dari pengembangan media pembelajaran Geoshapes Digital adalah untuk menjelaskan atau mendeskripsikan tahapan pengembangan Geoshapes Digital pada mata kuliah Pendidikan Matematika II dan untuk mendeskripsikan keefektifan dan kepraktisan pembelajaran dengan media Geoshapes Digital pada mata kuliah Pendidikan Matematika II. Model penelitian yang digunakan yaitu desain model Plomp yang memiliki tahap investigasi awal, perencanaan, realisasi dan tes, evaluasi. Validitas pada penelitian ini terdiri dari validitas materi dan media Geoshape digital. Sedangkan angket digunakan untuk mengukur ketertarikan mahasiswa sedangkan tes diukur untuk mendapatkan data terkait kemampuan pemahaman konsep. Dari hasil penelitian diperoleh bahwa media Geoshapes Digital sudah memenuhi kriteria valid dan praktis serta pembelajaan dengan media Geoshapes Digital juga dapat meningkatkan pemahaman mahasiswa ditunjukkan dengan rata-rata skor tes evaluasi mencapai 76 berdasarkan perhitungan uji t.
\end{abstract}

Kata kunci: media pembelajaran, Geoshapes digital, Pendidikan Matematika II

\section{GEOSHAPE DIGITAL: LEARNING MEDIA TO IMPROVE THE UNDERSTANDING OF ELEMENTARY SCHOOL MATHEMATICS CONCEPTS}

\begin{abstract}
Mathematics education II requires learning media as motivation that can increase student interest and understanding. It takes learning media that is innovative, interactive, and follows the development of information technology. Digital Geoshapes learning media as an alternative media in supporting the geometry material of the circumference and area of mathematics education courses II. The purpose of developing Digital Geoshapes learning media is to explain or describe the stages of developing Digital Geoshapes in Mathematics II education courses and to describe the effectiveness and practicality of learning with Digital Geoshapes media in the Mathematics Education II course. The research model used is the Plomp model design which has stages of the initial investigation, planning, realization and testing, evaluation. The validity of this study consisted of the validity of the digital Geoshape material and media. While the questionnaire was used to measure student interest, while the test was used to measure the ability to understand mathematical concepts. From the results of the study, it was found that the Geoshapes Digital media had met the valid and practical criteria, and learning with the
\end{abstract}


Digital Geoshapes media could also improve student understanding as indicated by the average evaluation test score reaching 76 based on the t-test calculation.

Keywords: learning media, digital Geoshapes, Mathematics Education II

\section{PENDAHULUAN}

Pada proses belajar diperlukan alat yang bisa merangsang pembelajaran yaitu media untuk pembelajaran. media untuk pembelajaran pada awalnya hanya sebagai alat bantu, dan hanya sebatas di visual. Seiring dengan perkembangan zaman, media pembelajaran tidak hanya visual saja, namun dilengkapi dengan audio bahkan bersifat interaktif. Semakin berkembangnya Ipteks di bidang pendidikan, penggunaan media pembelajaran menjadi berkembang seperti munculnya internet dan komputer. Media pembelajaran juga dapat meningkatkan motivasi dan minat serta pemahaman karena materi disajikan lebih menarik dan terpercaya.

Seperti yang diberitakan media online (Indriyani, 2014) bahwa prosentase penggunaan internet di pulau Jawa sangat tinggi mencapai 68\% dari jumlah penduduk di Pulau Jawa. Tingginya tingkat penggunaan internet di Pulau Jawa terutama ditemukan di kota-kota besar sebagai pusat jasa pendidikan dan hiburan, seperti DKI Jakarta, Yogyakarta, Bandung, dan Surabaya, kemudian diikuti oleh wilayah kabupaten/kota laindi sekitarnya (Mustari, \& Zain, 2012). Ini menunjukkan bahwa animo masyarakat dalam mengikuti perkembangan teknologi sangat tinggi. Oleh karena itu, hendaknya pemanfaatannya harus diarahkan dalam hal yang positif salah satunya adalah dalam pembelajaran. Walaupun perkembangan teknologi semakin pesat, namun demikian, Indonesia termasuk golongan tingkat rendah dalam penggunaan alat digital untuk pembelajaran (Latief, 2016).

Menurut data yang disajikan oleh BPS (2018), persentase siswa yang mengakses internet dari jenjang SD sampai dengan SMA sekitar 33,67\%. Persentase guru yang mempunyai kualifikasi bidang TIK hanya 10,10\%. Guru SMA lebih besar 14,43\% SMP 11,33\% dan SD sederajat 6,90\%. Hal ini menunjukkan rendahnya penggunaan TIK di sekolah terutama SD serta masih kurangnya kemampuan guru dalam melakukan pembelajaran berbasis TIK. Pada dunia pendidikan penggunaan 
ICT (Information Computer technology) sebagai penggunaan komputer dan teknologi informasi sangat memberikan pengaruh besar (Ulia, 2018).

Berdasarkan wawancara yang dilakukan kepada civitas academia Universitas Terbuka diperoleh asumsu bahwa Universitas Terbuka (UT) sudah melaksanakan pendidikan jarak jauh tentunya dalam hal perkembangan IT sudah sangat canggih dan maju. Universitas Terbuka (UT) sudah melaksanakan pendidikan jarak jauh tentunya dalam hal perkembangan IT sudah sangat canggih dan maju. Pembelajaran mandiri yang digalakkan oleh UT membuat mahasiswa terlatih untuk memahami materi secara mandiri melalui modul atau buku materi pokok yang sudah disediakan. Meskipun demikian, masih ditemukannya mahasiswa yang belum melaksanakan pembelajaran mandiri secara maksimal terlihat dari nilai akhir mata kuliah masih pada kriteria cukup. Berdasarkan observasi yang dilakukan oleh tutor saat monitoring pembelajaran jarak jauh di salah satu kabupaten, diperoleh fakta bahwa dalam pembelajaran baik tatap muka maupun online, tutor belum menggunakan media pembelajaran yang inovatif. Mahasiswa memerlukan media pembelajaran untuk memahami materi yang disampaikan. Modul yang diberikan belum cukup mampu untuk memberikan pemahaman terhadap mahasiswa dalam membantu untuk dapat mencapai hasil belajar yang maksimal. Dengan demikian, adanya media belajar dapat membantu tutor dalam menyampaikan dan memahamkan materi di modul karena sudah terbantu dengan media yang ada. Pembelajaran di Universitas Terbuka sudah menggunakan learning. Oleh karena itu, tentunya media yang perlu dikembangkan tidak berupa fisik, namun sudah berbasis digital.

Media sebagai alat atau sumber dalam belajar yang berupa fisik terdiri dari materi instruksional dan dapat merangsang untuk belajar. Sedangkan media pembelajaran merupakan media yang bertujuan untuk menyampaikan informasi baik instruksional atau untuk maksud pengajaran (Ulia, 2018). Menurut Briggs dalam Hamdani (2010) Media pembelajaran dapat membantu dalam menyajikan data agar lebih menarik, mempermudah dalam penafsiran data, dapat memadatkan informasi sehingga dapat meningkatkan pemahaman dalam pembelajaran karena motivasi dan minat peserta didik dapat dibangkitkan dengan media pembelajaran. Secara fisik media pembelajaran dapat berupa kaset, buku, video, gambar, 
computer, film dan lain sebagainya dapat digunakan sebagai sarana dalam menyampaikan materi pembelajaran.

Komputer sebagai produk dari perkembangan ilmu dan pengetahuan sangatlah membantu meringankan tugas manusia di berbagai segi kehidupan. Seperti contohnya dalam menghitung dan membantu dalam menyelesaikan administrasi. Selain mempunyai fungsi yang banyak, computer juga mudah diperoleh dan ditemukan diberbagai tempat. Begitu juga di bidang pendidikan terlebih Pendidikan Matematika, penggunaan komputer sangat diperlukan dan memberikan pengaruh dalam pembelajaran sebagai alat bantu yang digunakan guru saat mengajar. Pemanfaatan teknologi dapat dijadikan sarana oleh guru matematika dalam mengkomunikasikan ide-ide matematika.

Dengan memberdayakan teknologi maka akan dapat meningkatkan kualitas dalam pembelajaran. Komputer sangat berpotensi untuk menggeser paradigm pembelajaran dari ketrampilan manipulative ke pengembangan konsep, pemecahan masalah dan analogi. Komputer dapat dijadikan media dalam pembelajaran yang menarik bagi peserta didik dan membuat peserta didik merasa senang dalam belajar matematika (Ulia, 2018). Dengan komputer, pembelajaran matematika dapat dijadikan media dalam pengembangan ketrampilan dan pengembangan konsep. Dengan demikian komputer juga dapat dimanfaatkan dalam meningkatkan ketrampilan pemecahan masalah. Dengan demikian, haruslah teknologi yang efisien dan tepat dapat digunakan agar nantinya peserta didik dapat meningkatkan pemahaman, kemampuan berpikir matematika sehingga menjadi problem solver yang handal.

Pada mata kuliah Pendidikan Matematika II, mahasiswa akan mempelajari materi bangun datar yang mana merupakan salah satu pokok bahasan dalam materi geometri. Geometri sebagai cabang dalam ilmu matematika tentang bidangbidang baik datar maupun ruang. Materi geometri menjadi bagian penting dalam pembelajarn di Sekolah Dasar, oleh karena itu sebagai calon pendidik di SD perlu mendapatkan pembelajaran terkait geometri. Berdasarkan penelitian Rizky, A (2018) ditemukan fakta yang terjadi bahwa dalam pembelajaran geometri di Sekolah Dasar (SD) lebih ditekankan buku paket misal dalam menjelaskan rumus luas trapezium hanya sebatar gambar-gambar abstrak saja. Dengan demikian sangat diperlukan media pembelajaran yang lebih menarik dan inovatif sehingga 
pembelajaran lebih menarik dan mengingkatkan minat belajar. Untuk mempermudah mahasiswa dalam memahami materi dan mempermudah tutor dalam menyampaikan pembelajaran maka perlu menggunakan media pembelajaran. Selama ini penggunaan media pembelajaran baik berupa internet maupun media fisik sudah dilaksanakan. Mahasiswa mencari sumber belajar juga dengan memanfaatkan internet, namun belum bisa mengakomodir pengetahuan terkait konsep. Salah satu media pembelajaran yang dikembangkan adalah geoshape digital.

Geoshape digital sebagai alternatif media pembelajaran yang dapat dimanfaatkan oleh tutor dan mahasiswa yang dapat membantu dalam meningkatkan pemahaman konsep. Nama media Geoshapes Digital dibentuk dari gabungan kata geometri dan shapes yang disingkat Geoshapes dan karena berbasis Digital maka digabungkan menjadi geoshapes digital. Geoshapes Digital merupakan teknik mengidentifikasi bangun datar melalui beberapa gambar yang disajikan kemudian ketika di klik akan muncul materi dan soal terkait dengan materi KB II yaitu keliling dan luas bangun datar.

Digital sebagai produk dari ICT. Istilah ICT telah digunakan secara resmi oleh UNESCO (Ulia, 2018). Untuk saat ini ICT sebagai alat teknologi yang sangat diperlukan dalam memproses informasi, mengolah data, menyimpan dan mencari informasi dimana dan kapan saja. Pada saat ini, dimana terjadi perkembangan elektronik yang begitu pesat. Maka agar dapat dimanfaatkan dengan baik dalam meingkatkan kualitas belajar mengajar sehingga mampu dalam memecahkan permasaahan pendidikan terutama terkait pembelajaran, maka penggunaan ICT perlu diperhatikan dan dengan sungguh-sungguh ditangani secara professional.

Geoshapes Digital yang akan digunakan dikembangkan dengan aplikasi komputer. Dimana komputer menjadi media yang sangat diminati (Ulia, 2018). Maka media yang asalnya berupa benda konkret akan dibuat dengan aplikasi komputer sehingga menjadi media pembelajaran yang interaktif dan mempunyai tampilan visual yang bagus. Adapun karakteristik benda yang akan digunakan dalam media Geoshapes Digital berisi tentang materi geometri yang sedang dipelajari yang dibuat dengan aplikasi komputer sehingga mudah digunakan dan mendukung dengan pembelajaran digital yang diusung oleh Universitas Terbuka. Diharapkan dengan media pembelajaran Geoshapes Digital yang menggunakan 
komputer atau Digital mahasiswa lebih tertarik dalam memahami materi geometri khusunya pada KB II keliling dan luas pada mata kuliah Pendidikan Matematika II sehingga diharapkan kemampuan pemahaman konsep geometri mahasiswa dapat meningkat lebih baik.

Pada Mata kuliah Pendidikan Matematika II bertujuan agar mahasiswa terampil dalam melaksanakan pembelajaran keliling dan luas bangun datar, volume dan luas permukaan bangun ruang, pengukuran, simetri, matematika sosial, serta pengolahan data. Kemampuan tersebut sangat penting untuk dapat mengajar matematika kepada siswa SD sesuai dengan kurikulum SD. Selain materi matematika dalam mata kuliah Pendidikan Matematika II juga disajikan kesalahan dalam konsep yang banyak ditemukan dalam pembelajaran di kelas. Informasi tentang kesalahan konsep dalam pembelajaran diperlukan para guru sebagai masukkan dalam menentukan strategi pembelajaran matematika sehingga dapat memperkecil kesalahan konsep yang mungkin terjadi di dalam kelas. Dengan pengetahuan yang didapat, diharapkan mahasiswa menjadi guru yang profesional khususnya di dalam bidang matematika. Adapun materi yang terdapat pada mata kuliah Pendidikan Matematika II disajikan dalam 9 modul yang meliputi modul 1: bangun datar, modul 2: keliling dan luas, modul 3: bangun ruang, modul 4: volume bangun ruang, modul 5: simetri, modul 6: pengukuran I, modul 7: pengukuran II, modul 8: aritmetika, modul 9: pengolahan data.

Dalam mempelajari mata kuliah Pendidikan Matematika II, diharapkan mahasiswa terampil melakukan pembelajaran bangun datar sesuai dengan kurikulum SD, keliling dan luas segi banyak, lingkaran dan tangram dengan sifatsifatnya, sesuai dengan kurikulum SD, bidang banyak dan bangun ruang sesuai dengan kurikulum SD, volume dan luas bangun ruang sesuai dengan kurikulum SD, simetri sesuai dengan kurikulum SD, pengukuran panjang dan sudut sesuai dengan kurikulum SD, berat dan kecepatan sesuai dengan kurikulum SD, bank dan bendabenda pos sesuai dengan kurikulum SD, statistika sesuai dengan kurikulum SD.

Dari informasi diatas, terlihat bahwa pada modul 2 berisi materi tentang keliling dan luas bangun datar. Materi menghitung keliling sebuah bangun datar menjadi bagian dalam ruang lingkup geometri. Mahasiswa akan dituntun bagaimana memahami konsep keliling bangun datar dan bagaimana menghitung keliling suatu bangun datar. Begitu juga dengan materi luas. Dalam modul disajikan 
materi tentang konsep luas, bagaimana menghitung luas sebuah bangun datar dan juga disajikan kesalahan-kesalahan konsep luas.

Oleh karena itu, mahasiswa hendaknya membaca dan mempelajari konsepkonsep yang disajikan dalam mata kuliah ini dengan baik. Agar mahasiswa lebih cepat dalam mempelajarinya sebaiknya dilakukan dalam belajar kelompok, dan untuk memudahkan mahasiswa dalam menguasai materi yang ada dalam modul sehingga mahasiswa mampu mengerjakan semua tugas dan membuat rangkumannya.

Geoshapes Digital adalah media pembelajaran matematika yang nama tersebut diambil dari kata geo dan shapes dan terkait materi geometri yaitu bangun datar yang di sajikan dalam bentuk gambar menarik dan interaktif yang berupa gambar dua dimensi dalam bentuk digital yang yaitu berupa bangun datar geometri yang disajikan dalam bentuk aplikasi komputer. Geoshape dibuat dari aplikasi computer yang bersifat interaktif karena terdapat latiha, kuis serta soal yang secara langsung bisa dikerjakan. Diharapkan Geoshapes Digital dapat mamacu minat dan motivasi mahasiswa sehingga pembelajaran menjadi interaktif dan menarik, sehingga dapat menunjang materi keliling dan luas pada mata kuliah Pendidikan Matematika II sehingga pemahaman mahasiswa terhadap materi tersebut semakin baik dan meningkat.

Berdasarkan latar belakang tersebut, rumusan masalah dalam penelitian adalah Bagaimana tahapan pengembangan media pembelajaran Geoshapes Digital dalam menunjang Buku Materi Pokok KB II mata kuliah Pendidikan Matematika II? Dan Bagaimana kepraktisan dan keefektifan media pembelajaran Geoshapes Digital dalam menunjang Buku Materi Pokok KB II mata kuliah Pendidikan Matematika II?

Adapun Tujuannya adalah untuk mengetahui tahapan pengembangan media pembelajaran Geoshapes Digital dalam menunjang Buku Materi Pokok KB II mata kuliah Pendidikan Matematika II. untuk mengetahui kepraktisan dan keefektifan media pembelajaran Geoshapes Digital dalam menunjang Buku Materi Pokok KB II mata kuliah Pendidikan Matematika II. 


\section{METODE PENELITIAN}

Pada penelitian ini menggunakan desain penelitian R\&D yaitu pengembangan. Adapun yang dikembangkan adalah media Geoshape Digital. Metode dalam penelitian pengembangan merupakan metode penelitian untuk dapat menghasilkan produk tertentu, dengan menguji keefektifan produk tersebut (Ulia, Sari, \& Hariyono, 2020). Model pengembangan media adalah model dari Plomp dalam Rochmad (2012) dimana pada model ini sesuai dengan aliran kontruktivisme dimana desain pengembangan didasarkan pada mengkonstruk pemikiran. Adapun fase-fase pada desain Plomp terdiri dari fase investigasi awal, perancangan, konstruksi, dan fase validasi.

1. Tahap investigasi

Pada tahap ini dilakukan kajian dan identifikasi terkait materi dan kurikulum program studi PGSD. Selain itu juga dilakukan analisis tujuan pembelajaran yang dicapai dan analisis kompetensi kemudian juga dilakukan analisis terkait dengan media pembelajaran yang sudah dilaksanakan.

2. Tahap perancangan (desain)

Pada tahap desain terdapat beberapa aktivitas seperti membuat desain atau rancangan awal dari model pembelajaran geoshape digital. Rancangan awal pada tahap ini disebut sebagai draft 1 . Penyusunan rancangan didasarkan pada analisis tujuan pembelajaran, kompetensi dan materi. Rancangan produk nantinya akan divalidasi atau direview oleh pakar media dan materi. Review yang diberikan digunakan untuk masukan agar rancangan produk lebih sempurna. Selnjutnya juga akan dilakukan review kembali oleh validator ahli media dan materi.

3. Tahap konstruksi (realisasi)

Setelah dirancang, maka tahap selanjutnya adalah realisasi dan dihasilkan Draf 1 sebagai Draft awal. Adapun kegiatan pada tahap ini meliputi: penyusunan desain, menyususn algoritma program media, membuat script media dan membuat intrumen untuk pengumpulan data.

4. Tahap evaluasi dan revisi

Pada tahap evaluasi dan revisi ini terdapat kegiatan ujicoba dan validasi. pada kegiatan validasi menggunakan lembar angket validasi yang diberikan pada validator. Kemudian hasil analisis dari validator dijadikan bahan pertimbangan dalam pengembangan dan perbaikan produk. Uji validasi dilakukan berulang sampai 
dengan produk dinyatakan bisa digunakan. Jika hasil uji validasi dinyatakan valid tanpa reisi, maka produk dapat langsung digunakan. Jika uji validasi dinyatakan valid dengan sedikit revisi maka dilakukan perbaikan sesuai dengan saran dan masukan validator. Jika hasil uji validasi dinyatakan tidak valid, selanjutnya dilakukan revisi atau pembuatan draft baru dan dilakukan uji validasi ulang. Dari kegiatan validasi ini diharapkan diperoleh produk yang sudah dinyatakan valid.

Pada kegiatan uji coba dilakukan uji validasi, dan hasil dari uji validasi akan diperoleh apakah produk yang dikembangkan sudah memenuhi kriteria valid atau tidak. Kemudian pada tahap ini dilakukan uji kepraktisan terkait dengan respon mahasiswa terhadap media pembelajaran dengan menggunakan angket respon kepraktisan media. Setelah dilakuka uji kepraktisan pada tahap ini juga dilakukan uji keefektifan pembelajaran dengan menggunakan media geoshapes digital apakah dapat meningkatkan pemahaman konsep matematika mahasiswa. Uji keefektifan dianalisis dari tes baik dari pretes maupun postes. Uji coba kemudian dilakukan pada skala terbatas. Setelah dilakukan uji coba maka akan dianalisis data hasil uji coba dan kemudian dilakukan revisi berdasarkan analisis data tersebut.

\section{HASIL DAN PEMBAHASAN}

\section{Hasil Penelitian}

Berdasarkan data yang diperoleh dari hasil pengumpulan data dengan teknik servey, dokumentasi dan wawancara dengan Tutor dilingkungan UPBJJ Semarang, secara umum kemampuan pemahakan konsep matematika mahasiswa PGSD masih perlu ditingkatkan, terlihat dari nilai mata kuliah matematika pada kegiatan bantuan tutorial. Metode pembelajaran yang digunakan pada kelas tatap muka perkuliahan Pendidikan Matematika II masih berupa ceramah, tutor tidak menggunakan media pembelajaran apalagi berbasis teknologi computer atau digital. Kemungkinan ini dikarenakan belum adanya media yang dimaksud.

Ini juga terjadi pada tutorial online, dimana master tutorial online yang tersedia belum menyediakan media pembelajaran bagi mahasiswa untk memahami materi pada mata kuliah tersebut. Pada mata kuliah pendididikan Matematika 2 menggunakan Buku pegangan pokok PDGK 4206, berdasarkan capaian pembelajaran modul 2 merupakan titik awal dalam mengembangkan media pembelajaran Geohspe digital. 
Tahap perancangan media didesain secara manual diatas kertas (paper based) baik berupa gambar maupun teks dengan tujuan agar memperoleh gambaran apa saja yang akan ditampilkan pada media tersebut. Rancangan yang dibuat akan ditampilkan dalam program computer terutama terkait menu apa saja yang akan ditampilkan di media.

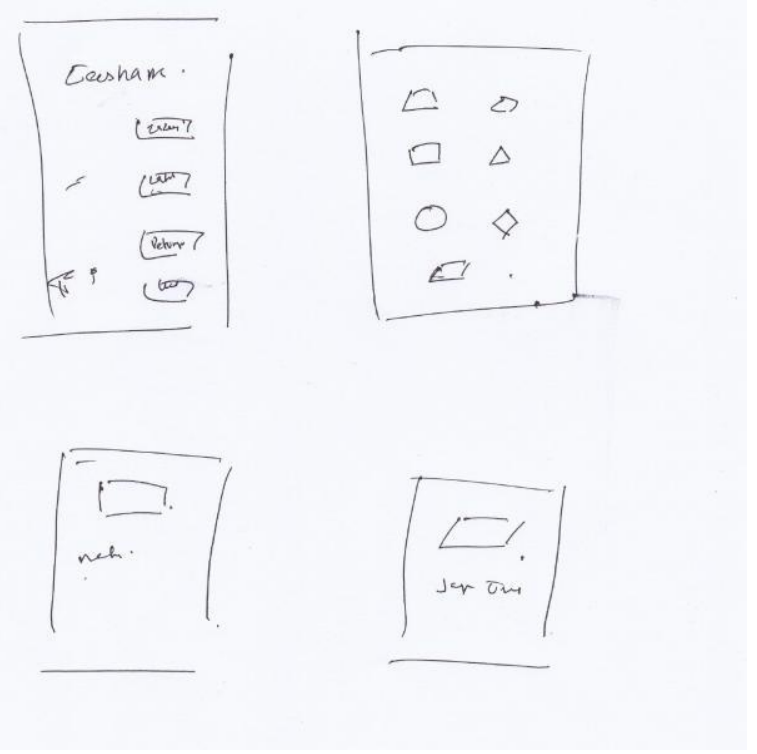

\section{Gambar 1. Hasil rancangan Paper-Based Geoshape}

Di dalam aplikasi Geoshape terdapat beberapa menu yaitu menu materi bangun datar, latihan soal, petunjuk dan menu keluar. Pada menu Keliling dan Luas terdapat materi terkait dengan jenis bangun datar yang bisa dipilih sesuai gambar bangun tersebut dan terdapat konsep luas dan keliling bangun datar tersebut. Media pembelajaran yang dibuat ini merupakan berbasis mobile learning, artinya mahasiswa dapat menginstall aplikasi tersebut ke handphone masing-masing yang menggunakan OS Android.

Desain media yang sudah dibuat pada tahap rancangan maka akan di realisasikan pada tahap realisasi dalam bentuk computer based. Hasil dari tahap realisasi disebut sebagai draft 1. 

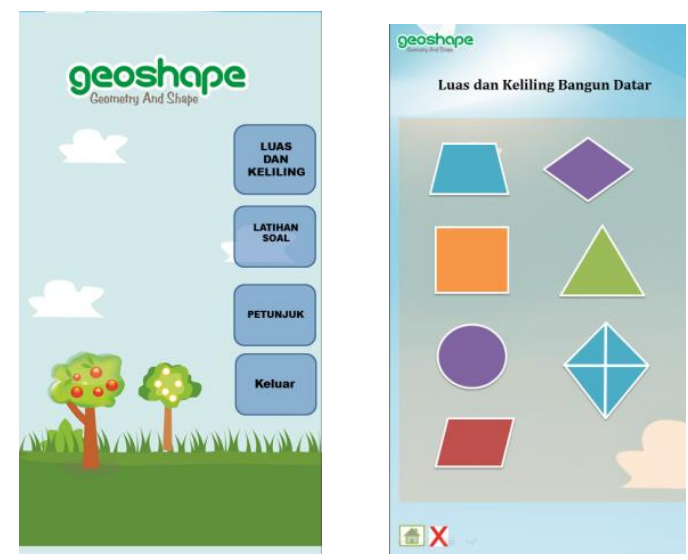

\section{Gambar 2. Hasil rancangan Computer-Based Geoshape}

Dari hasil penelitian diperoleh hasil validasi ahli yang dilakukan oleh validator pada kriteria baik. Validator atau orang yang melakukan uji validasi yang dilakukan oleh dua orang validator sebagai ahli media dan ahli materi. Dari hasil uji validasi diperoleh bahwa desain media geoshape digital sebagai draft 1sudah termasuk dalam kategori baik, dan ada saran-saran perbaikan dari validator. Misal seperti ukiran font huruf pada media lebih jelas lagi, pemilihan warna dan ditambahi iringan audio yang menambah semangat pada mahasiswa. Dari saran validator dijadikan pertimbangan untuk perbaikan dan hasil perbaikan produk disebut sebagai draft 2. Validator ahli materi juga memberikan saran terkait dengan konsep segiempat diberikan definisi yang lebih banyak lagi dari beberapa referensi. Hasil masukan validator digolongkan pada kategori revisi sesuai masukan dan tidak perlu uji validasi ulang. Draft 2 sebagai hasil perbaikan dari validator tidak diuji validasi ulang.

Selain itu, beberapa masukan dari validator terkait media geoshape digital diantaranya 1) beberapa link masih ditemukan error/bug, 2) perlunya ada toucsreen untuk navigasi, 3) soal-soal yang diberikan lebih variatif dan konstekstual. Adapun indicator soal terkait dengan kemampuan pemahaman siswa, 4) perlunya tambahan timer sebagai control mahasiswa dalam menyelesaikan soal, dan 5) perlunya ada petunjuk aplikasi yang lebih detail, karena petunjuk yang disampaikan masih terlalu sederhana. Dari hasil uji validasi diperoleh skor rata-rata 4,16 dengan kriteria baik dan dengan sedikit revisi. 
Penggunaan media pembelajaran Geoshape Digital perlu diukur bagaimana kepraktisan media Geoshape tersebut. Kepraktisan digunakan untuk mengukur sejauh mana media pembelajaran Geoshape mudah digunakan dalam pembelajaran dan tidak membebani guru dalam pelaksanaan. Kepraktisan produk dapat diartikan sebahzs sebagai upaya bagaimana melihat pendidik sebagai pengguna.

Dalam uji coba lapangan dilakukan pengamatan untuk melihat permasalahan yang terjadi pada proses pembelajaran menggunakan media Geoshape tersebut, sehingga dapat memberikan masukan untuk perbaikan media. Pembelajaran dilakukan dengan menggunakan laptop. Saat pembelajaran berlangsung dilakukan observasi terhadap peserta didik. Berdasarkan hasil observasi selama kegiatan pembelajaran mahasiswa masih awal penggunaan mereka kesulitan untuk menginstall di android, namun setelah mendapat arahan dengan mudah dapat menggunakan aplikasi tersebut karena aplikasi user frendly.

Mahasiswa juga diminta menjawab beberapa pertanyaan tentang media pembelajaran Geoshape tersebut. Jawaban mahasiswa akan digunakan sebagai acuan untuk memperbaiki Draf 1. Berdasarkan jawaban, komentar, dan saran yang diberikan mahasiswa maka secara umum dapat dikatakan bahwa Draf 1 sudah baik dan tergolong media yang praktis.

Uji efektivitas ini dilakukan untuk mengetahui apakah media pembelajaran Geoshape Digital efektif digunakan dalam pembelajaran matematika. Setelah dilakukan tes soal pemahaman konsep geometri bangun datar sebelum dan sesudah menggunakan media pembelajaran Geoshape Digital pada proses pembelajaran diperoleh hasil sebagai berikut:

Tabel 1. Nilai Rata-rata Pretes dan Postes

Pemahaman Konsep Geometri Bangun Datar

\begin{tabular}{|c|c|c|c|c|c|c|c|c|c|}
\hline \multirow{2}{*}{$\begin{array}{l}\text { Pemahaman } \\
\text { Konsep } \\
\text { Geometri } \\
\text { Bangun Datar }\end{array}$} & \multirow{2}{*}{$\begin{array}{l}\text { Skor } \\
\text { Maks } \\
\text { Tes }\end{array}$} & \multicolumn{4}{|c|}{ Kelas Eksperimen $(\mathrm{N}=\mathbf{2 1})$} & \multicolumn{4}{|c|}{ Kelas Kontrol ( $\mathrm{N}=23$ ) } \\
\hline & & $X_{\min }$ & $X_{\max }$ & $\overline{\boldsymbol{X}}$ & $S$ & $X_{\min }$ & $X_{\max }$ & $\overline{\boldsymbol{X}}$ & $S$ \\
\hline Pretest & 100 & 10 & 42 & 25,38 & 6,145 & 18 & 35 & 26,05 & 5,078 \\
\hline Postest & 100 & 56 & 94 & 76,00 & 9,326 & 46 & 88 & 68,05 & 8,678 \\
\hline
\end{tabular}


Tabel 2. Hasil Uji Perbedaan Rata-rata Skor Postes Pemahaman Konsep Geometri Bangun Datar

\begin{tabular}{ccccccc}
\hline Pretest & Kelas & $\overline{\boldsymbol{X}}$ & $\boldsymbol{t}$ & Df & Sig & Kesimpulan \\
\hline $\begin{array}{c}\text { Pemahaman } \\
\text { Konsep }\end{array}$ & Eksperimen & 76,00 & 3,770 & 71 & 0,000 & $\begin{array}{c}\text { Ada } \\
\text { Perbedaan }\end{array}$ \\
\hline
\end{tabular}

Setelah diperoleh data hasil pretes dan postes pada tabel di atas kemudian dilakukan uji perbandingan rata-rata peningkatan pemahaman konsep. Namun sebelum itu, dilakukan uji normalitas dan uji homogenitas dan diperoleh bahwa skor pretes dan postes kemampuan pemahaman konsep matematika kelas eksperimen dan kontrol berdistribusi normal dan homogen. Oleh karena itu uji perbedaan ratarata dua sampel yang digunakan adalah uji-t.

Berdasarkan tabel di atas menunjukkan bahwa nilai t sebesar 3,770 dengan derajat kebebasan sebesar 71 dan nilai signifikan (p-value) sebesar 0,00. Karena nilai signifikan ( $\mathrm{p}$-value) $<0,05$ maka hipotesis nol yaitu tidak terdapat perbedaan rata-rata postes kemampuan pemahaman konsep mahasiswa kelas eksperimen dan kontrol ditolak. Dengan kata lain, pemecahan masalah mahasiswa pada kedua kelompok setelah diberikan perlakuan adalah berbeda. Dalam hal ini berarti bahwa pemahaman konsep masalah mahasiswa yang menggunakan media pembelajaran Geoshape Digital lebih tinggi secara signifikan dibanding pemahaman konsep mahasiswa yang mengunakan media biasa. Dengan demikian Geoshape Digital yang sudah dikembangkan efektif dalam meningkatkan pemahaman konsep matematika materi geometri bangun datar.

\section{Pembahasan}

Berdasarkan hasil penelitian menunjukan bahwa pembelajaran Geoshape Digital mempunyai nilai rata-rata validator 4,16 dengan kriteria baik. Dari hasil penelitian yang diberikan oleh validator dengan nilai rata-rata diatas menunjukan bahwa pembelajaran Geoshape Digital dari segi tampilan, pemrogaman, dan materi berkriteria baik. Nilai hasil uji yang diperoleh dari respon mahasiswa terhadap penggunaan pembelajaran Geoshape Digital nilai rata-rata sebesar 4,05 dengan kategori baik. Hal ini menunjukan bahwa kebutuhan mahasiswa terhadap adanya media pembelajaran yang menarik, menantang dan interaktif sangat diperlukan. 
Tahap implementasi uji coba produk oleh mahasiswa menunjukan bahwa ada peningkatan dalam proses pembelajaran antara kelas yang menggunakan media pembelajaran Geoshape Digital rata-rata 76,05 dan kelas konvensional 68,05. Data kemudian dianalisis menggunakan analilsis uji beda rata-rata. Diperoleh hasil analisis data thitung 3,770 dengan derajat kebebasan 71 dan p-value 0,00 artinya pemahaman konsep pada kedua kelompok berbeda. Pemahaman konsep mahasiswa yang melakukan pembelajaran dengan media Geoshape Digital signifikan lebih tinggi daripada pemahaman konsep tanpa media Geoshape Digital. Pemahaman konsep menjadi hal dasar dalam pembelajaran matematika sehingga dangatlah penting. Dengan mengetahui suatu konsep, peserta didik mampu mengenal, menerangkan, memadukan, memisahkan, memberi sebuah contoh, menyimpulkan suatu objek serta mengungkapkan kembali dengan bahasanya sendiri (Kusumawati, K., Kusumadewi, R. F., \& Ulia, N. 2020).

Dari hasil uji keeftifan maka dapat ditunjukkan bahwa pembelajaran dengan media geoshapes dapat meningkatkan pemahaman konsep matematika. Dengan media pembelajaran berbasil digital tentunya mempunyai banyak keuntungan karena melalui media proses pembelajaran bisa lebih menarik dan menyenangkan dan dengan memperguna kan media yang tepat dan sesuai, akan dapat lebih mudah mengerti materi yang diajarkan (Chandra, Nugroho, \& Visual, 2016).

\section{SIMPULAN}

Karakteristik media pembelajaran Geoshape Digital adalah: 1) menggunakan komputer sebagai media pembelajaran; 2) Geoshape akronim dari Geometri dan Shape di dalam media pembelajaran ini materi-materi geometri kelilng dan luas bangun datar berbasis mobile learning; dan 3) aplikasi Geoshape sangat membantu mahasiswa dalam pemahaman konsep matematika metari geometri. Media pembelajaran Geoshape Digital berada pada kriteria valid. Hasil uji kepraktisan dinyatakan bahwa panduan berada pada kriteria sangat praktis. Hasil uji keefektifan dinyatakan bahwa media pembelajaran Geoshape Digital dinyatakan efektif untuk meningkatkan pemahaman konsep matematika mahasiswa. 


\section{DAFTAR PUSTAKA}

BPS. (2018). Publikasi hasil survey penggunaan dan pemanfaatan teknologi informasi dan komunikasi P2TIK sektor pendidikan 2018. Diterima dari https://www.bps.go.id/publication/.

Chandra, F. H., Nugroho, Y. W., \& Visual, D. K. (2016). Implementasi Student Centered Learning dengan memanfaatkan media pembelajaran digital dalam pembelajaran dengan menggunakan metode "Flipped Classroom". Media Prestasi, 18(2), 51-62.

Hamdani. (2011). Strategi belajar mengajar. Bandung: Pustaka Setia.

Indriyani. (November 2014). Penggunaan TIK naik 250 persen. ANTARA News. Diterima dari https://www.antaranews.com/berita/465411/penggunaantik-naik-250-persen.

Kusumawati, K., Kusumadewi, R. F., \& Ulia, N. (2020). Analisis pemahaman konsep matematika siswa SD pada model pembelajaran Problem Based Learning berbantuan media Pop Up. Prosiding Konferensi Ilmiah Mahasiswa Unissula (KIMU) Klaster Humanoira.

Latief. (2016). Adopsi alat digital untuk pembelajaran masih rendah. Kompas. Diterima dari https://edukasi.kompas.com/read/2016/08/31/21202221/adopsi.alat.digital .untuk.pembelajaran.masih.rendah.

Mustari, A. S., \& Zain, I. (2012). Analisis regresi tobit spasial studi kasus penggunaan internet di Pulau Jawa (Doctoral dissertation). Jurusan Statistika FMIPA ITS. Surabaya).

Rizky, A. (2018). Pembelajaran matematika materi geometri di SD Al Hikmah Surabaya. Jurnal Penelitian Pendidikan Guru Sekolah Dasar, 6(3).

Rochmad, R. (2012). Desain model pengembangan perangkat pembelajaran matematika. Kreano, Jurnal Matematika Kreatif-Inovatif, 3(1), 59-72.

Suherman,E.dkk. (2003). Strategi pembelajaran Matematika kontemporer. Bandung: UPI Bandung.

Ulia, N., Sari, Y., \& Hariyono, M. (2020). The influence of mathematical basic concept of materials based on internalization of Islamic values against religious attitude. Journal of Physics: Conference Series, 1517, 012060. 
Ulia, N. (2018). Efektivitas Colaborative Learning berbantuan media Short Card berbasis IT terhadap pemahaman konsep Matematika. Jurnal Ilmiah Pendidikan Dasar, 3(2), 1-11.

50 | Jurnal Ilmiah “Pendidikan Dasar” Vol. VIII No. 1 Januari 2021 